\title{
Functional lung rejuvenation in obese patients after bariatric surgery
}

Saulo Maia Davila Melo ${ }^{*}$, Pedro Alves Argentino², Murilo Matos de Santana Oliveira², Gabriela Nabuco Chaves Melo², GiLdo Lima Souza Neto²

${ }^{1} \mathrm{PhD}$ in Health Sciences - Universidade Federal de Sergipe. Full Professor, Medical School, Universidade Tiradentes, Aracaju, SE, Brazil

${ }^{2}$ Medical Student. - Universidade Tiradentes, Aracaju, SE, Brazil

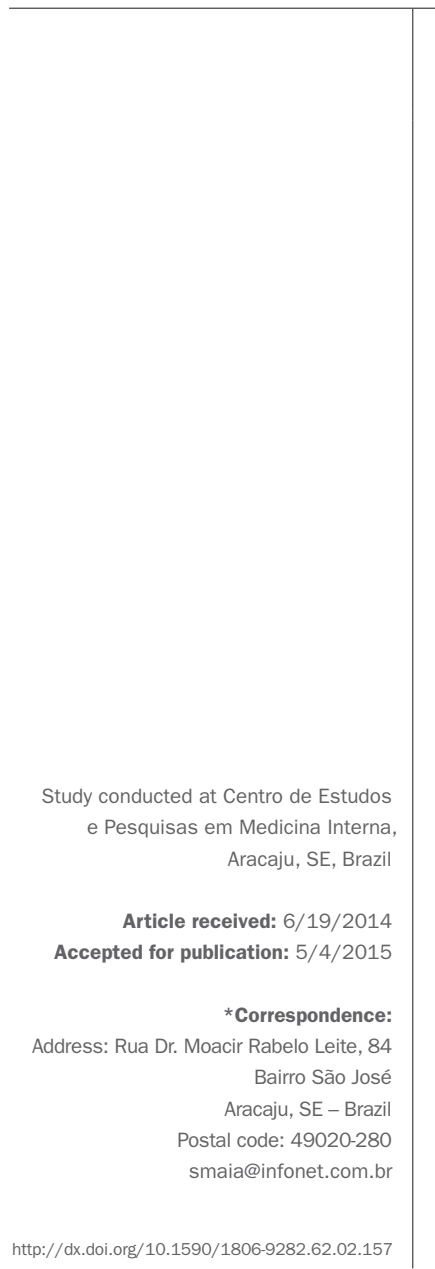

\section{SUMMARY}

Objective: To determine the lung age (LA) in obese people before and after bariatric surgery, compare the LA with the chronological age (CA) before and after the operation, and verify whether there was a functional pulmonary rejuvenation after it.

Methods: A prospective longitudinal study including 43 morbidly obese patients who underwent bariatric surgery. The patients underwent clinical and spirometric evaluation in two stages, before and after the surgery. In both stages, LA, CA and spirometric variables were measured.

Results: A significant improvement in the spirometric variables (FVC; $\mathrm{FEV}_{1}$; and $\mathrm{FEV}_{1} / \mathrm{FVC}$ ratio) was found after the operation ( $\mathrm{p} \leq 0.0001$ ). Comparing the LA before ( $50.93 \pm 13.36$ years) and after the surgery $(39.02 \pm 12.95$ years), there was an important reduction of $11.90 \pm 9.12$ years (95CI:9.10-14.71; $\mathrm{p} \leq 0.0001)$ in LA after surgery. The difference between LA and CA before surgery was $12.20 \pm 11.71$ years (95CI:8.60-15.81) with significant difference ( $\mathrm{p} \leq 0.0001)$, and the difference between LA and CA after surgery was $-1.95 \pm 11.83$ years (95CI: $-5.59-1.69)$ with no significant difference $(\mathrm{p} \leq 0.28)$. Regarding LA, we observed a pulmonary aging of $12.20 \pm 11.71$ years before the surgery and a pulmonary rejuvenation of $11.90 \pm 9.12$ years after it.

Conclusion: Morbid obesity is responsible for early damage and functional accelerated pulmonary aging. After the correction of the body weight by surgery, there is a functional pulmonary rejuvenation demonstrated by the normalization of LA in relation to CA.

Keywords: Lung diseases, premature aging, morbid obesity, spirometry, respiratory function tests, bariatric surgery.

\section{INTRODUCTION}

The consistent and significant growth of obesity in the last two decades, regardless of age, gender and socio-economic conditions of the population has become a problem of public and economic health for the World Health Organization (WHO). ${ }^{1}$

In Brazil, recent data showed that $51 \%$ of the population is overweight and $17 \%$ obese (16\% of men vs. $18 \%$ women), with a staggering advance in recent years, and with frightening forecasts for all regions of the country. ${ }^{2}$

Several comorbidities are caused by excess body weight and obesity is a major independent risk factor of premature death. ${ }^{3-5}$
Obesity is a chronic systemic inflammatory disease that early compromises lung function. ${ }^{6}$ Lung function decreases faster when the lungs are attacked by gases, toxic fumes, other pollutants, and inflammatory lung disease. ${ }^{7,8}$

Chronic inflammatory diseases cause progressive and early decline of cellular homeostasis, predisposing to an accelerated aging of the affected organs. ${ }^{7}$

The aging process is characterized by anatomical and functional changes, which vary greatly from person to person and in different organs, influenced not only by the passing of time, but also by lifestyle and sociocultural factors. ${ }^{9,10}$ 
Lung age (LA) is increased in obese patients before surgery for morbid obesity, suggesting premature and accelerated lung aging. ${ }^{6}$

To our knowledge, the concept of LA to assess the functional lung rejuvenation in obese patients after weight loss has never been used.

We hypothesized that obese undergoing bariatric surgery present preoperatively with early and accelerated functional lung aging when we compare LA with chronological age (CA), and that after bariatric surgery, with consequent weight loss, the mechanical effects and the inflammatory process caused by obesity in the lungs will be reduced, providing the pulmonary functional rejuvenation from the recovery of LA.

The aim of this study was to determine the spirometric LA in obese individuals without pulmonary disease, preand post-bariatric surgery; to compare LA and CA before and after bariatric surgery; and to verify whether there was spirometric lung rejuvenation after bariatric surgery.

\section{Methods}

This is a longitudinal, prospective study conducted at the Center for Studies and Research in Internal Medicine in the city of Aracaju, Sergipe, Brazil, between January 2010 and September 2012.

43 morbidly obese patients were selected for the study. They underwent clinical evaluation and spirometry in a private respiratory medicine practice by an assistant pulmonologist to determine lung surgical risk for surgical obesity treatment in the bariatric surgery clinic of two institutions, one public and one private. Obesity was classified according to World Health Organization (WHO) criteria for body mass index (BMI), obtained based on the weight $/$ height equation ${ }^{2}\left(\mathrm{~kg} / \mathrm{m}^{2}\right)$. Indications for surgical treatment followed the guidelines of the $\mathrm{WHO}$ and the Brazilian Ministry of Health. ${ }^{1,2}$

The study was approved by the Ethics Committee on Human Research of the Federal University of Sergipe (CAAE Extension 0050.0,107,000-07) and performed in two stages, before and after bariatric surgery. All participants signed a free and informed consent form. Preoperatively, patients were referred and evaluated consecutively, according to the demand of the clinic. For the evaluation after surgery, patients were invited by telephone to participate in the study as volunteers, randomly, provided that they had lost $20 \%$ or more of body weight and had at least six months of surgery.

Patients with any acute or chronic pulmonary disease were excluded, as well as active smokers and former smokers with any current or previous smoking history, incapacity to perform spirometry, and patients younger than 20 years according to the original formula for LA.

After clinical evaluation, body weight was obtained with the patient being asked to remove shoes and heavy clothing, and height was obtained using an anthropometer coupled to the scale that met the criteria for weight measurement evaluation of the morbidly obese.

Spirometry was performed using a computerized spirometer (Microlab-3500, Cardinal Health U.K. 232 Ltd.; England), with the patient in a sitting position and using a nose clip performing at least three forced expiratory maneuvers that met the acceptability and reproducibility criteria required by the current recommendations of the SBPT11, being selected the best of them. Forced vital capacity (FVC), forced expiratory volume in one second $\left(\mathrm{FEV}_{1}\right)$ and $\mathrm{FEV}_{1} / \mathrm{FVC}$ ratio were measured before the bronchodilator (pre-BD), with values expressed in liters and in percentage of the normal values calculated according to the equation by Hankinson et al. ${ }^{12}$

The patient's LA was estimated during spirometry using Pre-BD FEV ${ }_{1}$. The minimum pre-established LA was 20 years, the maximum LA being represented by the highest value in the original LA formula (Table 1$) \cdot{ }^{13}$

TABLE 1 Original formula for calculating lung age (years). ${ }^{11}$

Men: Lung age $=2.87 \times$ height $-\left(31.25 \times \mathrm{FEV}_{1}\right.$ obtained $)-39.375$

Women: Lung age $=3.56 \times$ height $-\left(40.00 \times \mathrm{FEV}_{1}\right.$ obtained $)-77.280$

Lung age in years; height in inches; 1 inch: 2.54 centimeters; $\mathrm{FEV}_{1}$ in liters.

Statistical analysis was performed with Statistical Package for the Social Sciences software, version 15 (SPSS Inc., Chicago, IL, USA). Categorical data are presented in absolute and percentage value, and the numeric data in average and standard deviation. 95CI was calculated for LA and CA in both stages. To determine the differences in continuous variables within one step and between steps, paired Student $t$ test was used. Statistical significance was set at $\mathrm{p}<0.05$, and all statistical tests were two-tailed.

\section{RESULTS}

Table 2 illustrates a comparison of the preoperative and postoperative stages including demographic, anthropometric and spirometric characteristics of the population studied.

The average time between bariatric surgery and postoperative evaluation was $14.0 \pm 8.7$ months.

In the sample, 30 (69.8\%) patients were women, with CA average before surgery of $38.72 \pm 10.12$ years $(95 \mathrm{CI}$ : $35.61-41.84)$ and, after surgery $40.98 \pm 10.35$ years $(95 \mathrm{CI}$ : 
$37.79 \pm 44.16), p \leq 0.001$. There was a significant reduction in BMI between the two stages of evaluation (44.18 \pm 7.4 and $29.06 \pm 4.6 \mathrm{~kg} / \mathrm{m}^{2}$, respectively; $\left.\mathrm{p} \leq 0.0001\right)$.

As for the evaluated spirometric variables $\left(\mathrm{FEV}_{1}, \mathrm{FVC}\right.$ and $\mathrm{FEV}_{1} / \mathrm{FVC}$ ratio), a significant improvement after bariatric surgery $(\mathrm{p} \leq 0.0001)$ was observed.

Table 3 compares the CA and LA before and after bariatric surgery, displaying the differences between CA and LA in each step and between steps. Comparing the LA before (50.93 \pm 13.36 years; 95CI: 46.82-55.04) and after surgery (39.02 \pm 12.95 years; 95CI: 35.04-43.01), we found a significant reduction in LA after surgery of $11.90 \pm 9.12$ years (95CI: 9.10-14.71; $\mathrm{p} \leq 0.0001)$.

\section{TABLE 2 Demographic, anthropometric and spirometric} characteristics before and after bariatric surgery in the studied population.

\begin{tabular}{llll} 
Variables & Before $(\mathbf{n}=43)$ & After $(\mathbf{n}=43)$ & $\mathbf{P}$ \\
\hline Aged $^{\mathrm{b}}$, years & $38.72 \pm 10.12$ & $40.98 \pm 10.35$ & 0.001 \\
\hline Gender female $^{\mathrm{a}}$ & $30(69.8)$ & - & \\
\hline Skin color, White & $30(71)$ & - & \\
\hline $\mathrm{BMI}^{\mathrm{b}}, \mathrm{Kg} / \mathrm{m}^{2}$ & $44.18 \pm 7.45$ & $29.06 \pm 4.66$ & $0.0001^{*}$ \\
\hline $\mathrm{FEV}_{1}{ }^{\mathrm{b}}, \mathrm{L}$ & $2.72 \pm 0.59$ & $3.04 \pm 0.78$ & $0.0001^{*}$ \\
\hline $\mathrm{FEV}_{1}{ }^{\mathrm{b}}, \%$ foreseen & $82.41 \pm 8.13$ & $93.69 \pm 9.90$ & $0.0001^{*}$ \\
value & & & \\
\hline $\mathrm{FVC}^{\mathrm{b}}, \mathrm{L}$ & $3.25 \pm 0.74$ & $3.51 \pm 1.87$ & $0.0001^{*}$ \\
\hline $\begin{array}{l}\mathrm{FVC}^{\mathrm{b}}, \% \text { foreseen } \\
\text { value }\end{array}$ & $80.53 \pm 8.33$ & $87.95 \pm 9.87$ & $0.0001^{*}$ \\
\hline $\mathrm{FEV}_{1} / \mathrm{FVC}^{\mathrm{b}}, \%$ & $82.90 \pm 7.69$ & $86.69 \pm 7.15$ & $0.01^{*}$
\end{tabular}

BMI: Body mass index; absolute and relative spirometric values (pre-bronchodilator). $\mathrm{FEV}_{1}$ : Forced expiratory volume in one second. FVC: Forced vital capacity. FEV $/$ /FVC: \% of $\mathrm{FEV}_{1} / \mathrm{FVC}$ ratio. a: Values expressed as n (\%). b: Values expressed as average \pm SD. *Student's t test.

TABLE 3 Comparison between chronological age and lung age before and after bariatric surgery; at each stage and between stages.

\begin{tabular}{llllll} 
Variables & $\begin{array}{l}\text { Before } \\
(\mathbf{n = 4 3})\end{array}$ & $\mathbf{9 5 C l}$ & $\begin{array}{l}\text { After } \\
(\mathbf{n = 4 3 )}\end{array}$ & $\mathbf{9 5 C l}$ & $\mathbf{P}$ \\
\hline CA, years & $38.72 \pm 10.12$ & $35.61-$ & $40.98 \pm 10.35$ & $37.79-$ & 0.001 \\
& & 41.84 & & 44.16 & \\
\hline LA, years & $50.93 \pm 13.36$ & $46.82-39.02 \pm 12.95$ & 35.04 & 0.0001 \\
& & 55.04 & & -43.01 & \\
\hline LA - CA, & $12.20 \pm 11.71$ & 8.60 & $-1.95 \pm 11.83$ & -5.59 & 0.0001 \\
years & & 15.81 & & -1.69 & \\
\hline
\end{tabular}

CA: Chronological age; LA: Lung age; LA - CA: Difference between lung age and chronological age. Values expressed as average \pm SD. Student's $t$ test.

The difference between LA and CA before surgery was $12.20 \pm 11.71$ years (95CI:8.60-15.81) with a significant difference $(\mathrm{p} \leq 0.0001)$, and the difference between LA and
CA after surgery was $-1.95 \pm 11.83$ years (95CI: $-5.59-1.69$ ) with no significant difference ( $\mathrm{p} \leq 0.28)$.

Figure 1 is a graphic demonstration of CA differences before and after bariatric surgery, as well as LA before and after surgery, also displaying the differences between CA and LA at every stage, and between stages. Preoperatively, the comparison between LA and CA demonstrates an accelerated early functional lung aging $12.20 \pm 11.71$ years with a significant difference $(\mathrm{p} \leq 0.0001)$. Postoperatively, the comparison between LA and CA revealed that there was no significant difference between them ( $\mathrm{p} \leq$ $0.28)$, so that the patients showed practically the same chronological and lung ages (LA - CA: $-1.95 \pm 11.83$ years).

Thus, comparing LA before and after bariatric surgery, we found functional lung rejuvenation in the study sample of $11.90 \pm 9.12$ years (95CI 9.10-14.71) after surgery.

\section{Discussion}

This study showed that obese patients scheduled for bariatric surgery have an early and accelerated functional aging (12.20 \pm 11.71 years), and that after bariatric surgery there is a functional lung rejuvenation $(11.90 \pm 9.12$ years $)$ evidenced based on the concept of LA.

In a previous study, we have demonstrated an accelerated early lung aging (12.20 \pm 2.4 years) in a group of morbidly obese patients previously to bariatric surgery compared with a group of non-obese controls, ${ }^{6}$ which corroborates our results of early lung aging around a decade.

To our knowledge, there are no studies in the literature evaluating functional lung rejuvenation in obese patients after correction of body weight using the concept of LA.

The segment of obese population is increasing alarmingly in both the developed and developing world; however, there are few studies on the impact of obesity on the

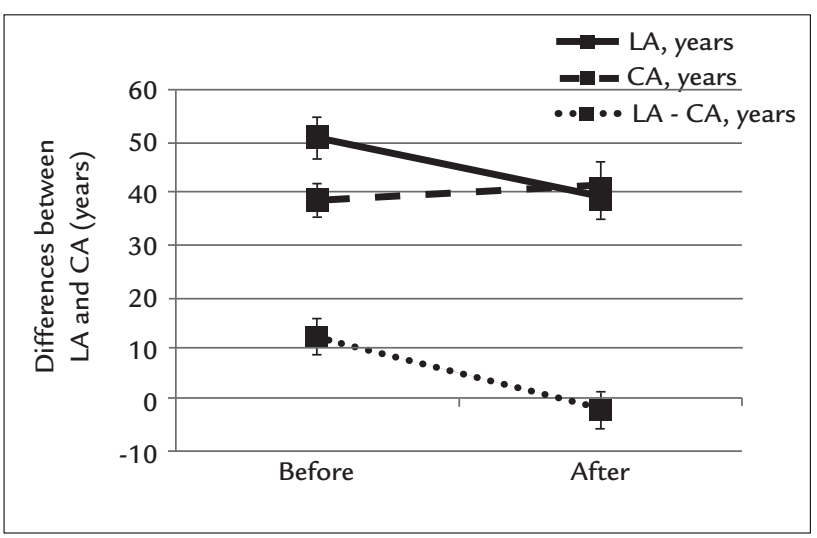

FIGURE 1 Comparison between chronological age and lung age before and after bariatric surgery; at each stage and between stages. 
lungs, despite the clear effect of obesity on lung function as a result mainly of the mechanical and inflammatory effects of excessive weight. $3,5,14,15$

With increasing degree of obesity, the mechanical effects are attributed to increased intra-abdominal pressure and decreased compliance of the rib cage (pulmonary and chest wall) caused by excessive fat tissue in these sites and the impairment of respiratory muscles with decreased diaphragmatic displacement capacity and overload of the inspiratory muscles, reducing FVC and $\mathrm{FEV}_{1},{ }^{3,5}$

$\mathrm{FEV}_{1}$ is an independent factor of cause of death and a risk factor for sudden death, cancer and cardiovascular disease. ${ }^{5,11}$

$\mathrm{FEV}_{1}$ is influenced by FVC and is part of the formula of lung age, ${ }^{13}$ which explains in our study the increased lung age (accelerated early functional lung aging) justified by the reduction in $\mathrm{FEV}_{1}$ in morbidly obese patients preoperatively, with $\mathrm{FEV}_{1} / \mathrm{FVC}$ ratio being preserved.

After bariatric surgery with correction of body weight, there is a recovery of lung function with improvement in FVC and $\mathrm{FEV}_{1} \cdot{ }^{16}$ Our results demonstrate similar results, with improved $\mathrm{FEV}_{1}$ after bariatric surgery, justifying lung rejuvenation seen in our sample.

Whenever LA is in disagreement with CA, obese patients may be warned of the early detection of lung damage (accelerated early functional aging) that can be prevented or controlled with the reduction in body weight (functional lung rejuvenation). However, one must be careful not to translate to the patient the concept of LA as a life expectancy, but only alert of accelerated early pulmonary function damage and the real possibility of functional recovery after correction of body weight.

It is now known that adipose tissue is not simply an inert body to store energy. Rather, it is a great source of production of pro-inflammatory mediators, working as an endocrine organ that regulates systemic inflammation producing a variety of acute phase proteins (adipocytokines), the main being leptin, which has pro-inflammatory action, and adiponectin with anti-inflammatory activity. In obese people, there is a reduction in serum adiponectin and an increase in leptin, establishing a lowgrade chronic inflammation with systemic and pulmonary repercussions. ${ }^{14,15,17}$

The aging process is for life; it is incredibly complex and heterogeneous, and is characterized by anatomical and functional changes. However, there are diseases that accelerate aging. ${ }^{6-8,15,18}$ The main preventive measure to combat obesity is to encourage the correction of the patient's body weight, using every tool available. The concepts of LA and pulmonary functional rejuvenation have this purpose.
This study shows some limitations. In our research, we do not enter into the merits of the mechanisms of aging and senescence involving molecular biology, changes in morphology, and cellular respiratory function. Our goal is to demonstrate the functional spirometric alterations in the obese that, after correction, translates into significant functional recovery. Our attempt is to convey the message functional modification of the lungs in obesity, and the possibility of recovery, using the new concept of functional lung rejuvenation. This is an idea that can be easily understood by the patient, lay people and health professionals, so that they become aware of the serious effect of obesity on the lungs, and use this tool to combat this serious epidemic.

Future research should assess the psychological strength of the concept of LA to demonstrate accelerated early lung aging and spirometric lung rejuvenation, as a warning tool and additional incentive to the treatment of obesity in our country.

\section{Conclusion}

Summing up, morbid obesity causes early damage and accelerated functional lung aging, which is demonstrated by the discrepancy between chronological age and lung age. After correction of the body weight using bariatric surgery, there is functional lung rejuvenation, translated by the normalization of lung age in relation to chronological age.

\section{Resumo}

Rejuvenescimento pulmonar funcional em pacientes obesos após cirurgia bariátrica

Objetivo: determinar a idade pulmonar (IP) em obesos no pré e pós-operatório de cirurgia bariátrica, comparar a IP com a idade cronológica (IC) antes e após a cirurgia, e verificar se houve rejuvenescimento pulmonar funcional após a cirurgia.

Métodos: estudo longitudinal, prospectivo, envolvendo 43 pacientes obesos mórbidos submetidos à cirurgia bariátrica. Os pacientes foram submetidos à avaliação clínica e espirométrica antes e após a cirurgia, sendo determinadas IP, IC e variáveis espirométricas.

Resultados: observou-se melhora significativa nas variáveis espirométricas $\left(\mathrm{VEF}_{1}, \mathrm{CVF}\right.$ e razão $\left.\mathrm{VEF}_{1} / \mathrm{CVF}\right)$ após a cirurgia $(\mathrm{p} \leq 0,0001)$. Comparando a IP antes $(50,93 \pm 13,36$ anos) e após a cirurgia (39,02 $\pm 12,95$ anos), observou-se redução significativa da IP no pós-operatório de 11,90 $\pm 9,12$ anos (IC 95\% 9,10-14,71; $\mathrm{p} \leq 0,0001$ ). A diferença entre IP 
e IC no pré-operatório foi de 12,20 11,71 anos (IC 95\% $8,60-15,81)$ com diferença significativa $(\mathrm{p} \leq 0,0001)$. A diferença entre IP e IC no pós-operatório foi de -1,95 $\pm 11,83$ anos (IC 95\% -5,59-1,69), sem apresentar diferença significativa $(\mathrm{p} \leq 0,28)$. Quando comparamos a IP antes e após a cirurgia, observamos um envelhecimento pulmonar de $12,20 \pm 11,71$ anos antes e um rejuvenescimento pulmo-

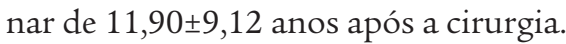

Conclusão: a obesidade mórbida causa dano precoce e envelhecimento pulmonar funcional acelerado. Após a correção do peso corpóreo pela cirurgia, há um rejuvenescimento pulmonar funcional, mostrado pela normalização da IP em relação à IC.

Palavras-chave: pneumopatias, senilidade prematura, obesidade mórbida, espirometria, testes de função respiratória, cirurgia bariátrica.

\section{References}

1. World Health Organization. Obesity and overweight. Geneva: World Health Organization [cited 2014 Jan 2]. Available from: http://www.who.int/ mediacentre/factsheets/fs311/en/index.html.

2. Brasil. Ministério da Saúde. Mais da metade da população brasileira tem excesso de peso. Brasília: Ministério da saúde, 2013 [cited 2014 Jan 2]. Available from: http://portalsaude.saude.gov.br/portalsaude/noticia/12926/162/maisda-metade-da-populacao-brasileira-tem-excesso-de-peso.html.

3. Koenig SM. Pulmonary complications of obesity. Am J Med Sci. 2001; 321(4):249-79.
4. Poulain M, Doucet M, Major GC, Drapeau V, Sériès F, Boulet LP, et al. The effect of obesity on chronic respiratory diseases: pathophysiology and therapeutic strategies. CMAJ. 2006; 174(9):1293-9.

5. McClean KM, Kee F, Young IS, Elborn JS. Obesity and the lung: 1 . Epidemiology. Thorax. 2008; 63(7):649-54.

6. Melo SM, Melo VA, Melo EV, Menezes Filho RS, Castro VL, Barreto MSP. Accelerated lung aging in patients with morbid obesity. J Bras Pneumol. 2010; 36(6):746-52.

7. Ito K, Barnes PJ. COPD as a disease of accelerated lung aging. Chest. 2009; 135(1):173-80.

8. Papaioannou AI, Rossios C, Kostikas K, Ito K. Can we delay the accelerated lung aging in COPD? Anti-aging molecules and interventions. Curr Drug Targets. 2013; 14(2):149-57.

9. Caruso LB, Silliman RA. Medicina geriátrica. In: Fauci AS, Braunwald E, Kasper DL, Hauser SL, Longo DL, Jameson JL, et al. (eds.). Harrison Medicina Interna. 17.ed. Rio de Janeiro: McGraw-Hill Interamericana do Brasil, 2008. p.53-62.

10. Costa EFA, Galera SC, Porto CC, Cipullo JP, Martin JFV. Semiologia do idoso. In: Porto CC (ed.), Porto AL (co-ed.). Semiologia médica. 6.ed. Rio de Janeiro: Guanabara Koogan, 2011. p.159-93.

11. Sociedade Brasileira de Pneumologia e Tisiologia. Diretrizes para testes de função pulmonar. J Pneumol. 2002; 28(3):S2-S238.

12. Hankinson JL, Odencrantz JR, Fedan KB. Spirometric reference values from a sample of the general U.S. population. Am J Respir Crit Care Med. 1999; 159(1):179-87.

13. Morris JF, Temple W. Spirometric "lung age" estimation for motivating smoking cessation. Prev Med. 1985; 14(5):655-62.

14. Mancuso P. Obesity and lung inflammation. J Appl Physiol. 2010; 108(3):722-8

15. Sood A. Obesity, adipokines, and lung disease. J Appl Physiol (1985). 2010; 108(3):744-53.

16. Santana AN, Souza R, Martins AP, Macedo F, Rascovski A, Salge JM. The effect of massive weight loss on pulmonary function of morbid obese patients. Respir Med. 2006; 100(6):1100-4.

17. Ali Assad N, Sood A. Leptin, adiponectin and pulmonary diseases. Biochimie. 2012; 94(10):2180-9.

18. Ito K, Colley T, Mercado N. Geroprotectors as a novel therapeutic strategy for COPD, an accelerating aging disease. Int J Chron Obstruct Pulmon Dis. 2012; 7:641-52. 